\title{
Effect of Temperature and pH on Growth of Alternaria tagetica, Leaf Blight of Marigold
}

\author{
Karuna Chandrakant Kurhade', Hanumant Dnyandeo Gangawane', \\ C.D. Deokar ${ }^{2}$, K.S. Raghuwanshi ${ }^{3}$
}

PGI, Mahatma Phule Krishi Vidypeeth, Rahuri-413 705, Maharashtra, India.

Received: June 2021

Accepted: July 2021

\begin{abstract}
Marigold (Tagets erecta) is one of the most important major floriculture crop in India. The leaf blight of marigold is caused by Alternaria tagetica is becoming a common disease on marigold Alternaria blight appeared in mild to severe form in many regions of Maharashtra and sometimes resulting in complete failure of the crop especially during rainy season. The fungal pathogen are greatly influenced by environmental factor therefore the present work undertaken to study the effect of temperature and $\mathrm{pH}$ on growth of Alternaria tagetica. The effect of temperature and $\mathrm{pH}$ were determined by colony diameter method by using different media like potato dextrose agar and oat meal agar medium. It is clearly evident from the result that all the temperature $\mathrm{pH}$ tested showed variation in the diameter of colony. The temperature $25^{\circ} \mathrm{C}$ encouraged better growth of Alternaria tagetica as compared to $15^{\circ} \mathrm{C}$ and $35^{\circ} \mathrm{C}$. The result also revealed that $\mathrm{pH} 6$ and 7 encouraged better growth of Alternaria tagetica it is concluded from the result that temperature $25^{\circ} \mathrm{C}$ and $\mathrm{pH} 6$ is optimum temperature and $\mathrm{pH}$ for the growth Alternaria tagetica.
\end{abstract}

Key words: Alternaria tagetica, $\mathrm{pH}$, Soyabean, Temperature.

\section{INTRODUCTION}

Marigold (Tagetes L.) is a flowering plant belonging to the family Asteraceae. The name Tagetes come from the name of the "Etruscan Tages". Marigold was first time discovered by the Portuguese in Central America in the $16^{\text {th }}$ century, and is a native of North and South America. The most commonly cultivated varieties of Tagetes are African marigold (Tagetes erecta) and French marigold (Tagetes patula).

In India marigold is mainly cultivated in the states of Karnataka, Madhya Pradesh, Maharashtra, West Bengal, Haryana, Delhi and Himachal Pradesh. In Maharashtra, marigold is cultivated in an area over 3760 hectares with a production of 23820 metric tonnes of flowers (indiastat 2016). Although, the area under marigold cultivation is increasing year after year but overall yield with regard to flower production per unit area is fluctuating because of incidence of diseases in the crop. Different diseases are observed on the marigold among this in recent years, Alternaria blight appeared in mild to severe form in many regions of Maharashtra and sometimes resulting in complete failure of the crop especially during rainy season.

The phyllosphere of plants is a dynamic ecosystem inhabited by specific bacteria, yeasts and fungi. Their activity is related to various interactions between the biotic and abiotic factors of the environment (Thakur and Harsh, 2014). Abiotic factors includes Temprature, $\mathrm{pH}$, Humidity, Light intensity etc. whereas biotic factors include pest and other microorganisms, these microorganisms will compete with pathogenic species this phenomenon called antagonistic activity and it has been studied by many researcher (Kumar, 2008; Panwar et al., 2013).

The effect of $\mathrm{pH}$, incubation temperature, light regime and type of culture media on the mycelial growth of $A$. alternata causing leaf blight of noni has been studied in vitro in agar plates and it is found to be sensitive to nutritional and environmental factor and their growth and sporulation are therefore greatly influenced by the composition of the temperature and $\mathrm{pH}$ (Hubballi et al., 2010). The present work has therefore undertaken to study effect of these factors on the growth of Alternaria tagetica causing leaf blight of marigold.

\section{MATERIALS AND METHODS}

Alternaria tagetica was isolated from the infected leaves of marigold. After performing their pathogen city test their culture was maintained on potato dextrose agar medium at $25 \pm 1^{\circ} \mathrm{C}$.

\footnotetext{
${ }^{*}$ Corresponding author's E-mail: kurhadekaruna@gmail.com

'PGI, Mahatma Phule Krishi Vidypeeth, Rahuri-413 705, Maharashtra, India.

'Division of Plant Pathology, College of Agriculture, Dhule-424 004, Maharashtra, India

${ }^{3}$ Rice Pathologist, Agricultural Research Station, Lonawla-410 401, Maharashtra, India.
} 


\section{Effect of temperature}

To study the optimum temperature requirement for the mycelial growth and sporulation of test pathogen, temperatures ranging from 0 to $35^{\circ} \mathrm{C}$ were studied on PDA medium. Twenty milliliter sterilized PDA was poured in sterilized Petri plates. The Petri plates were inoculated with five $5 \mathrm{~mm}$ disc of 7 days old culture of test pathogen as mentioned earlier in 3.4.1.1 and the inoculated plates were separately incubated at $0,5,10,15,20,25,30$ and $35^{\circ} \mathrm{C}$. Four replications were taken for each temperature level. Observations on the mycelial growth $(\mathrm{mm})$ and spore production of test pathogen were recorded after 7 days of incubation.

\section{Effect of $\mathrm{pH}$}

Different $\mathrm{pH}$ levels i.e. 2, 3, 4, 5, 6, 7, 8 and 9 were evaluated to study the influence of hydrogen ion concentration on the mycelial growth and spore production of test pathogen on PDA. The $\mathrm{pH}$ of the media was adjusted by adding $0.10 \mathrm{~N}$ $\mathrm{HCl} / \mathrm{NaOH}$, with the help of electronic $\mathrm{pH}$ meter. Twenty milliliter sterilized PDA was poured in sterilized Petri plates. Petri plates were inoculated with 7 days old culture and incubated at $25 \pm 1^{\circ} \mathrm{C}$ temperature for 7 days. Four replications were maintained for each $\mathrm{pH}$ level. Observations on the mycelial growth $(\mathrm{mm})$ and spore production of the pathogen were recorded after 7 days of incubation.

\section{RESULTS AND DISCUSSION} Effect of temperature on mycelium growth

Influence of temperatures on the mycelial growth and sporulation of Alternaria tagetica were determined on PDA. The inoculated Petri plates with Alternaria tagetica were exposed to $0,5,10,15,20,25,30$ and $35^{\circ} \mathrm{C}$. Observations on the mycelial growth $(\mathrm{mm})$ and sporulation were recorded after seven days of incubation. The data obtained are presented in Table 1.

It is clear from the results that the pathogen could grew well between 20 to $30^{\circ} \mathrm{C}$. Significantly highest mycelial growth $(63.25 \mathrm{~mm})$ with excellent sporulation was observed at $25^{\circ} \mathrm{C}$, which was followed by $30^{\circ} \mathrm{C}(48.50 \mathrm{~mm})$ and $20^{\circ} \mathrm{C}$ $(31.12 \mathrm{~mm})$ with excellent to moderate sporulation, respectively. Lower temperature i.e. $15^{\circ} \mathrm{C}(15.75 \mathrm{~mm})$ revealed poor mycelial growth and meager sporulation of Alternaria tagetica. Temperatures less than $10^{\circ} \mathrm{C}$ did not supported mycelial growth and sporulation. It is revealed from the results that $25^{\circ} \mathrm{C}$ temperature found most suitable for the mycelial growth and sporulation of Alternaria tagetica on PDA. Results similar to the present investigation giving best mycelial growth and sporulation of Alternaria tagetica at $25^{\circ} \mathrm{C}$ was observed by Singh et al. (2001). Further Singh and Majumdar (2004) recorded highest Alternaria fruit rot severity at $25^{\circ} \mathrm{C}$ in pomegranate. Panchal (2008) observed excellent mycelial growth and sporulation of Alternaria alternata infecting tomato at $25^{\circ} \mathrm{C}$.
Table 1: Effect of temperature on the mycelial growth of Alternaria tagetica.

\begin{tabular}{lcc}
\hline Temperature & Mycelial growth $(\mathrm{mm})$ & Sporulation \\
\hline $0^{\circ} \mathrm{C}$ & 0.00 & - \\
$5^{\circ} \mathrm{C}$ & 0.00 & - \\
$10^{\circ} \mathrm{C}$ & 0.00 & - \\
$15^{\circ} \mathrm{C}$ & 15.75 & ++ \\
$20^{\circ} \mathrm{C}$ & 31.12 & +++ \\
$25^{\circ} \mathrm{C}$ & 63.25 & ++++ \\
$30^{\circ} \mathrm{C}$ & 48.50 & ++++ \\
$35^{\circ} \mathrm{C}$ & 29.87 & ++ \\
S. Em. \pm & 0.45 & \\
C.D. at $1 \%$ & 1.74 & \\
C.V. $\%$ & 3.82 & \\
\hline
\end{tabular}

- No spore production +++ Good spore production

+ Poor spore production $\quad++++$ Excellent spore production

++ Moderate spore production

Table 2: Effect of $\mathrm{pH}$ on the mycelial growth and sporulation of Alternaria tagetica.

\begin{tabular}{lcc}
\hline $\mathrm{pH}$ & Mycelial growth $(\mathrm{mm})$ & Sporulation \\
\hline 2 & 0.00 & - \\
3 & 0.00 & - \\
4 & 32.37 & ++ \\
5 & 48.12 & +++ \\
6 & 56.00 & ++++ \\
7 & 68.00 & ++++ \\
8 & 64.25 & +++ \\
9 & 54.25 & +++ \\
S. Em. \pm & 0.98 & \\
C.D. at $1 \%$ & 2.88 & \\
C.V. $\%$ & 4.90 & \\
\hline
\end{tabular}

\begin{tabular}{ll}
\hline - No spore production & +++ Good spore production \\
+ Poor spore production & ++++ Excellent spore production \\
++ Moderate spore production &
\end{tabular}

\section{Effect of $\mathrm{pH}$ on mycelium growth}

Eight $\mathrm{pH}$ levels were studied to determine the effect of hydrogen ion concentrations on the mycelial growth and sporulation of Alternaria tagetica and the results achieved are presented in Table 2. The data presented in Table 2 revealed that significantly highest mycelial growth $(68.00$ $\mathrm{mm}$ ) and excellent sporulation was recorded in $\mathrm{pH} 7$ followed by $\mathrm{pH} 8(64.25 \mathrm{~mm})$. The alkaline $\mathrm{pH}$ supported better mycelial growth than acidic one. However, at $\mathrm{pH} 2$ and 3 pathogen failed to produce mycelial growth. The lower $\mathrm{pH}$ levels had detrimental effect on the mycelial growth and sporulation of Alternaria tagetica. The results of present investigations are similar to the results obtained by Gaddanakeri et al. (1998) recording maximum mycelial growth of Alternaria alternata causing blight of turmeric at 
$\mathrm{pH}$ 6.5. Further, Kumar and Choudhary (2006) recorded maximum biomass production of $A$. brassicae and $A$. brasssicola infecting Indian mustard at $\mathrm{pH} 6.0$.

\section{REFERENCES}

Gaddanakeri, M. and Kulkarni, S. (1998). Physiological studies on Alternaria alternata (Fr.) Keissler a causal agent of leaf blight of turmeric. Karnataka J. of Agri. Sci. 11(3): 684- 686.

Hubballi, M., Sevugapperumal, N., Raguchander, T., Anand, T. and Ramasamy, S., (2010). Effect of environmental conditions on growth of Alternaria alternata causing leaf blight of Noni. World J. of Agri. Sci. 6(2): 171-177.

Kumar Arun, G.S., (2008). Studies on Leaf Blight of Chrysanthemum Caused by Alternaria alternata (Fr.) Keissler. Master of Science (agriculture) in Plant Pathology. Department of Plant Pathology College of Agriculture, Dharwad University of Agricultural Sciences.

Kumar, D. and Choudhary, U. (2006). In vitro evaluation of role of hydrogen ion concentration on mycelial growth and sporulation of A.brassicae and A. brassicola. J. of Res. SKUAT-J. 5(1): 122-124.
Panchal, D.G. (2008). Alternaria fruit rot of tomato (Lycopersicon esculentum Mill.) and its management. M. Sc. thesis Submitted to Anand Agricultural University, Anand.

Panwar, V., Gangwar, R.K., Javeria, S. and Yadav, R.S., (2013). Antifungal efficacy of fungicides and bio-control agents against leaf spot pathogen, Alternaria alternata. Current Discovery. 2:128-133.

Singh, J. and Majumdar, V.L. (2004). Factor affecting development of post harvest Alternaria rot in pomegranate. J. Mycol. PI. Pathol. 34(2): 310-311.

Singh, V., Kumar, P. and Sinha, A.P. (2001). Influence of different media, $\mathrm{pH}$ and temperature on growth and sporulation of Alternaria alternata (Fr.) Keissler, causing alternaria blight of chickpea. Legume Research. 24(2): 238-242.

Thakur, S. and Harsh, N.S.K., (2014). Phylloplane fungi as biocontrol agent against Alternaria leaf spot disease of (Akarkara) Spilanthes oleracea. Biosci. Disc. 5(2): 139-144. 